\title{
Research Based Learning: Added Value in Students' Science Critical Thinking Skills
}

\author{
Jessy Viny Reyk ${ }^{1}$, Marleny Leasa ${ }^{*}$, Melvie Talakua1, John Rafafy Batlolona ${ }^{2}$ \\ ${ }^{1}$ Elementary School Teacher Education Study Program, Faculty of Teacher Training and Education, Pattimura University, Ambon, \\ Indonesia \\ ${ }^{1}$ Physics Education Study Program, Faculty of Teacher Training and Education, Pattimura University, Ambon, Indonesia.
}

DOI: $\underline{10.29303 / \text { ippipa.v8i1.1121 }}$

\section{Article Info}

Received: November 10, 2021

Revised: January 10, 2022

Accepted: January 15, 2022

Published: January 31, 2022

\begin{abstract}
Many new learning models in the 21st century have emerged in improving students' academic skills, one of which is research-based learning (RBL). This pedagogic and constructivist model connects research and learning in improving students' critical thinking skills (CTS). The results of the study show that studies in empowering students' CTS using RBL are still limited. Therefore, exploration and deeper measurement of CTS with the RBL model were carried out through this study. The purpose of this study was to improve students' CTS using the RBL learning model. The results of the ANCOVA test showed that there was an effect of the RBL model in improving students' CTS. Descriptive data also shows that the average value of CTS is 72.70 using RBL, while students who take part in learning using conventional models show an average value of critical thinking skills of 58.30. Thus, RBL can be recommended in increasing the CTS of elementary school students in science learning.
\end{abstract}

Keywords: 21st century skills; Critical thinking skills; RBL model

Citation: $\quad$ Reyk, J. V., Leasa, M., Talakua, M., \& Batlolona, J. R. (2022). Research Based Learning: Added Value in Students' Science Critical Thinking Skills. Jurnal Penelitian Pendidikan IPA, 8(1), $230-238$. https://doi.org/10.29303/jppipa.v8i1.1121

\section{Introduction}

Learning in the 21st century requires students to have good conceptual and skills to live in the future. Global data informs that the United States Ministry of Education ordered to declare $4 \mathrm{C}$ as an essential skill needed by an individual in collaboration, communication, creativity, and critical skills in students from kindergarten to grade 12 (Kettler, 2014). They believe in $4 \mathrm{C}$, individuals who can communicate well with their peers and collaborate with their environment in harmony can also think creatively and critically to face new environments (Bağ \& Gürsoy, 2021). According to the results of a comprehensive Delphi study by 46 leading experts stating that critical thinking is an assessment that aims for an individual to be selfcontrolled and not emotional so that it will result in interpretation, analysis, evaluation, and inference, as well as explanations of evidentiary, conceptual, methodological considerations, criteria or contextual basis for consideration (Facione, 1990).
Critical thinking skills (CTS) are a product of western education. In this modern era, CTS has spread in non-western countries. It can be seen from nonwestern academics voicing their support for the inclusion of critical thinking in education. They are non-Western countries such as Malaysia (Tee, et al., 2018), Singapore (Cheong \& Cheung, 2008), and Taiwan (Wang, et al., 2017). Research studies on critical thinking have been carried out in several countries such as Iran, Vietnam, Jordan, Turkey, Nigeria, South Korea, Oman, Taiwan, and even Indonesia. (Solihati \& Hikmat, 2018).

CTS is also an important attribute that becomes the primary goal and ideals in education and learning (Polat \& Aydin, 2020). CTS as one's navigator in the making a decision (Samaras, et al., 2021), equips individuals to participate in today's rapidly changing democratic society. In addition, CTS is highly valued because it makes a person successful in studies and the world of work (van der Zanden, et al., 2020). CTS is also a mental process to analyze the information 
obtained. The information is obtained through observation, experience, communication, or reading. The teacher must provide opportunities for students to convey ideas on a given problem to develop CTS. When the ideas are conveyed, the teacher evaluates various aspects in the form of understanding, knowledge, and thoughts of what is conveyed because each student has different dimensions of critical thinking in terms of cultural, social, and scientific abilities (Gumus, et al., 2013).

CTS has high implications for students' active mentality in solving problems (Anderson \& Good, 2020). The results of the study explain that CTS is underdeveloped in science learning in elementary schools (Vidergor, 2018). This is because teachers lack good conceptual skills in stimulating students' critical thinking (Wartono, et al., 2018). Skilled teachers will make their students critical. Otherwise, unskilled teachers will make students uncritical and incompetent (Leasa et al., 2020). The development of science and technology today is so fast that students are more intelligent and critical in learning.

Science learning is a well-organized and systematic collection of knowledge related to natural phenomena in the form of living and non-living objects (Darling-hammond, et al., 2019). Science puts forward facts, concepts, principles, and procedures that are scientifically tested. People who study science are highly motivated and make science a hobby because they have interesting topics to research. Scientists often spend a lot of time and money pursuing their interest in developing skills. In addition, they continue to learn from various sources in the form of books, findings, and even discussions with their community. One of them is the USA which is developing rapidly in science, so they build research centers for research and take them as a country that excels in science (Corin et al., 2017). On average, they spend less than $5 \%$ of their lives studying in a formal educational setting and, as a result, it is clear that most scientific knowledge is learned outside of school in various competitions and meetings. (National Research Council, 2014); (Falk et al., 2018).

Science learning is more effective if it involves environmental observations and provides direct learning experiences (Volet, et al., 2019). It is evident from education in Sweden. It was started in 1990, prioritizing and capturing children's interest in learning and development with a pedagogic approach. In addition, fun scientific collaborative activities can generate positive emotions and social interactions that support the learning process (Gustavsson, et al., 2016). It is assumed and demonstrated that when teachers engage students through fun science learning and create good opportunities for students to develop an understanding of science concepts and the value of science as a discipline, it can build their confidence and encourages future engagement and long-term interest.

Actual conditions show that the implementation of learning is still thoroughly dominated by teachers and still adheres to the old paradigm, namely the flow of knowledge is obtained by being given or taught by more intelligent people, such as teachers (Garrett, 2008; Aarto-Pesonen \& Piirainen, 2020). The literature shows that the involvement of professional teachers in learning will have a positive impact on students' knowledge, attitudes, and skills, resulting in better teaching quality (Bellibaş \& Gümüş, 2021). The active teachers and students' acceptance pattern is still being practiced in traditional classes (Leasa, et al., 2016). Therefore, the student-centered learning approach has not been fully integrated into learning. As a result, the quality of learning is not visible in stimulating CTS (van Peppen, et al., 2018).

The explanation above is supported by several studies that prove the lack of critical thinking skills, as evidenced by the findings of Leasa \& Corembima (2016). It measured CTS in Ambon City with a value of 53.41 with a medium-level category. The measurement of creative thinking skills of elementary school students in Maluku was only able to achieve a score of 20-30s with low category (Leasa, et al., 2021). Why does this happen? The quality of students or the quality of teachers may encourage the unexpected results obtained by students. The instruments and learning models used are only to train the level of cognitive achievement, namely remembering (Leasa, et al., 2019). Cognitive instruments that teachers generally train for students in learning seem only to train lower levels of cognitive achievement, including $\mathrm{C} 1, \mathrm{C} 2, \mathrm{C} 3$, and $\mathrm{C} 4$, while levels $\mathrm{C} 5$ and $\mathrm{C} 6$ are the least commonly found so that the knowledge formed in students is too low, so unable to stimulate thinking at a higher level (Tuaputty, 2021).

Learning oriented to critical thinking activities can be carried out by teachers using specific learning models such as RBL. Thus, it is expected to make students more active and increase their curiosity, spirit, enthusiasm, and understanding in carrying out experiments to find material concepts independently. RBL educates students to do their research with the assistance of a teacher. RBL is currently seen as a panacea to overcome various demands in higher education, long-term social benefits because it can encourage scientific careers, shape someone to become a future scientist, help develop the mindset of researchers in solving problems, and develop cognition and motivation. (Wessels, et al., 2020).

RBL is inquiry-based learning, links research and learning in an academic environment (Yeoman \& Zamorski, 2008). The presence of RBL because of the 20th Century, the University is more positioning itself 
as a teaching-based campus. Therefore, campus in the 21st Century is transformed into a campus that not only carries out education and learning for students but is research-based (Al-Maktoumi, et al., 2016). The RBL model is beneficial for students to know the content of the material, but they also have the opportunity to practice researching by working in groups or individually to solve problems, to encourage the development of CTS (Smith \& Rust, 2011). The RBL model is excellent because it changes the way students think in uncovering unknown things to improve learning aspects of cognitive, affective, and psychomotor content (Espinoza-Figueroa, et al., 2021). Implementing RBL can solve several aspects, for example, research design, data collection, practical research, and interpretation of results (Brew \& Saunders, 2020). So far, the RBL model for developing critical thinking has not been studied much in science learning in elementary schools. Thus, this research was raised and explored more deeply. This study aimed to analyze the effect of the RBL learning model on students' CTS in science learning.

\section{Method}

The type of research used was quasi-experimental, using the research design "Nonequivalent Control Group Design." This design was implemented to investigate the effect of the RBL model on students' CTS according to Table 1.

Table 1. The Research Design of Pretest and Posttest Control Group Design

\begin{tabular}{cccl}
\hline $\begin{array}{l}\text { Groups } \\
\text { Experiment }\end{array}$ & Pretest & Treatment & Posttest \\
Control & $\mathrm{O} 1$ & $\mathrm{X}$ & $\mathrm{O} 2$ \\
$\begin{array}{c}\text { Where: } \\
\mathrm{X} \quad:\end{array}$ & $\begin{array}{l}\text { The treatment is the application of learning by } \\
\text { using the Research Based Learning model }\end{array}$ \\
$(-) \quad:$ & $\begin{array}{l}\text { Treatment in the form of conventional learning } \\
\mathrm{O}_{1}:\end{array}$ & $\begin{array}{l}\text { Test To measure students' } \\
\text { understanding (Pretest) }\end{array}$ \\
$\mathrm{O}_{2}: \begin{array}{l}\text { Test to determine the level of } \\
\text { misconceptions (Posttest) }\end{array}$ &
\end{tabular}

The population in this study were all 4th-grade students of Batumiau Christian Elementary School, Leti Island, Southwest Maluku Regency. Class 4 has two classes, namely class A and B. The sampling technique used the cluster random sampling method so that the experimental group was treated using the RBL model, namely class A with 30 people, and the control group was treated using a conventional model, namely class B with a 30 person.

The main instrument used in this study was the CTS test instrument with 10 questions. The question instrument developed had been validated by two science learning experts from Pattimura University. The instrument used in this study refers to five CTS indicators: understanding the problems in the questions given, providing reasons based on relevant evidence, making appropriate conclusions, using all appropriate information to the problem, and providing further explanations (Ennis, 2015). The CTS instrument has been tested empirically before being implemented in the experimental class. The CTS instrument had been tested on 4 elementary schools in Ambon City and 2 elementary schools on Moa Island, Southwest Maluku Regency, in 5th-grade students who had studied the material according to the CTS questions given. The number of students who were tested was 150 people, and the results of the validity and reliability tests were and 0.384 respectively.

The research procedure consisted of several stages. The first stage was the selection of schools to be studied. The second stage was selecting the experimental group and the control group with the Cluster random sampling method. The third stage was testing the assessment instrument in grade 4 with 30 students. The number of questions was 10 items in the form of essays. The questions given had been categorized as valid. The next stage was to give a pretest to both groups using the same questions. Then, the experimental class and the control group were given different treatments. The experimental group was treated using the RBL model, while the control group was treated using a learning model that was often used by teachers at the school on light material and its properties. In the final stage, the posttest was given to both groups using the same questions.

The data obtained were analyzed based on techniques including descriptive analysis, assumption test or prerequisite test, and hypothesis testing. After being tested for normality and homogeneity, the average difference for the achievement of each class was carried out. It was done to find out whether there was a difference in the average for the achievement of the two groups. The analysis used was ANCOVA test analysis with a significance level of 0.05 on SPSS 23 Software.

\section{Result and Discussion}

Before carrying out the learning process in class, the first thing that must be done was a prerequisite test, namely a normality test on the pretest value, to see if the data were normally distributed or not. The normality test results showed that the Sig-pretest value in the experimental class was 0.065, while the Sigpretest value in the control class was $0.054>$ Alpha 0.05 . it means that the data was declared normal. As for the homogeneous test, the Sig-pretest value was 0.601 . Then the same thing was done on the posttest value, 
where the results of the normality test for the Sigposttest value in the experimental class was 0.801 while the Sig-posttest value in the control class was $0.128>$ 0.05 . It means that the test data from both classes were normal, and the homogeneous value was 0.139. After it was proven that the data were normal and homogeneous, the ANOVA test was performed. To ensure equality in the two groups, namely RBL and Conventional. ANOVA results show the value of Sig $(0.985)>$ alpha (0.05). It means that there is no CTS difference between the two groups, and both are equivalent.

The prerequisite tests that must be met were the normality and homogeneity tests of the data. The normality test is used to determine whether the data from the tests carried out are normally distributed or not, using the One-Sample Kolmogorov Smirnov. Meanwhile, the homogeneity test was carried out to prove whether the pretest and posttest data were homogeneous or not, using Leven's Test of Equality of Error Variances in SPSS 23 Software. The results of the prerequisite test data are shown in Table 2. Normality and homogeneity tests of the data were carried out on two groups, namely the experimental group, and control group.

The results of the data normality test showed that the pretest data had a value of Sig (0.065) and (0.054)>
(0.05). It means that the pretest data were normally distributed in the experimental and control groups. The same result was also shown for the posttest data, where the values of Sig $(0.128)$ and $(0.139)>(0.05)$. It means that the posttest data are normally distributed. The results of the homogeneity test obtained Sig values $(0.601$ and 0.801$)>0.05$ alpha. It means that the two data were homogeneously distributed. Based on the results of the analysis of the prerequisite tests carried out, it can be stated that the research data for the results of the pretest and posttest were normally distributed, and the variance between the experimental class and the control class was homogeneous. Therefore, data analysis could be continued to the next test, namely hypothesis testing.

Hypothesis testing can use the posttest value of the experimental group, which was treated using the RBL learning model, and the control group using the conventional learning model. This hypothesis test aimed to find out the difference between the RBL model and the conventional model on students' CTS. The results of statistical analysis of ANCOVA analysis variables related to CTS are shown in Table 3.

Table 2. The Normality and Homogeneity Test Results of Critical Thinking Variable Data

\begin{tabular}{|c|c|c|c|c|c|c|}
\hline \multirow{2}{*}{ Variable } & \multirow[t]{2}{*}{ Prerequisite Test } & \multicolumn{4}{|c|}{ Signifikansi (2-tailed) } & \multirow[t]{2}{*}{ Alpha } \\
\hline & & Pretest & & Posttest & & \\
\hline Critical & Group & Experiment & Control & Experimen & Control & \\
\hline Thinking & Normality & 0.065 & 0.054 & 0.128 & 0.139 & 0.05 \\
\hline & Homogenity & 0.601 & & 0.801 & & \\
\hline
\end{tabular}

Table 3. Students ANCOVA CTS Test

\begin{tabular}{llllll}
\hline Source & Type III Sum of Squares & Df & Mean Square & F & Sig. \\
\hline Corrected Model & $2694.029 \mathrm{a}$ & 2 & 1347.014 & 7.886 & 0.001 \\
Intercept & 4187.439 & 1 & 4187.439 & 24.516 & 0.000 \\
Pretest & 0.629 & 1 & .629 & .004 & 0.952 \\
Learning Model & 2693.173 & 1 & 2693.173 & 15.767 & 0.000 \\
Error & 9735.971 & 57 & 170.807 & & \\
Total & 273790.000 & 60 & & & \\
Corrected Total & 12430.000 & 59 & & & \\
\hline
\end{tabular}

In the learning model, it can be seen that the calculated $F$ is 15.767 with a significance of 0.000 , far below the value of $\mathrm{Sig}<0.05$, so it can be concluded that there is a difference in student CTS between those who took part in learning using the RBL model and the

Table 4. Corrected CTS Average Score

\begin{tabular}{lllll}
\hline Learning Model & CTS Pretest & CTS Posttest & Difference & Corrected Average \\
\hline RBL & 50.80 & 72.70 & 21.90 & 72.70 \\
Conventional & 50.77 & 58.73 & 7.96 & 59.30 \\
\hline
\end{tabular}

The average corrected value for CTS in the experimental group was 72.70 , while the average corrected score in the control group was 59.30. It shows conventional model. The CTS corrected average value is in the Table 4. that the treatment given to the experimental group is more effective than the treatment to the control group. 
Then, the $\mathrm{N}$-gain test was used to analyze to strengthen the experimental group's effectiveness.

The results of the N-Gain analysis on student test results on the topics studied showed that the highest score of the experimental group treated using the RBL model is on the topic of light can propagate straight, light can penetrate clear objects, and light can be reflected. Then, the highest score for the control group using conventional models is on the topic of refracted light, dispersion light, and analyzing the properties of images on plane mirrors, concave mirrors, and convex mirrors. Meanwhile, the lowest value from the experimental group is on the topic of light refraction, dispersion light, and analyze the nature of the image on a plane mirror, concave mirror, and convex mirror, and the lowest value of the control group is on the topic of light can propagate in a straight line, light can penetrate clear objects and light can be reflected. It can be seen in the diagram below.

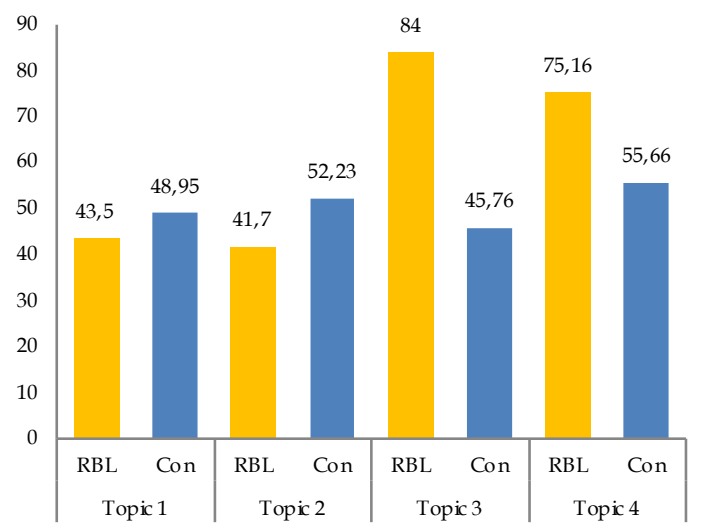

Figure 1. The average CTS score of students on each topic studied

Note:

Topic 1 : Light can propagate in straight lines and light can pass through clear objects

Topic 2 : Light can be refracted and light can be dispersed

Topic 3 : Light can be reflected

Topic 4 : Analyzing the properties of images on plane, concave, and convex mirrors

The description of the pretest and posttest scores obtained by students in the treatment using the RBL and conventional models can be seen in Table 5 .

Table 5. Pretest, posttest, and N-Gain scores for CTS

\begin{tabular}{|c|c|c|c|c|}
\hline \multirow[t]{2}{*}{ Description } & \multicolumn{2}{|l|}{ RBL } & \multicolumn{2}{|c|}{ Conventional } \\
\hline & Pretest & Posttest & Pretest & Posttest \\
\hline $\begin{array}{l}\text { The Highest } \\
\text { Score }\end{array}$ & 60 & 90 & 60 & 86 \\
\hline $\begin{array}{l}\text { The lowest } \\
\text { score }\end{array}$ & 40 & 50 & 40 & 33 \\
\hline Average & 51 & 73 & 51 & 59 \\
\hline
\end{tabular}

Table 5. shows that the highest pretest and lowest pretest values in the experimental group treated using the RBL model and the control group treated using the conventional model were the same. Meanwhile, the experimental group's highest posttest value and the lowest posttest value were higher than the control group.

After being treated using a different model for the two classes, it can be seen in the posttest scores stating that the CTS of the experimental group students was more improved than the control group because the learning process was carried out according to the RBL syntax, where students had many opportunities to improve understanding skills in the classroom through experiments. Students who were treated using the conventional model did not have a syntax, where students were only glued to the explanation from the teacher, causing only a few students to be active. If the learning process did not use a learning model, $60 \%$ of the classroom would be controlled by students, and if the learning process did not use a learning model, $80 \%$ of the classroom would be controlled by the teacher. The learning process using the RBL model had such a great effect. The background of RBL is research-based learning, so the teacher will direct students to do practicum according to the materials that the teacher has prepared. Students will do a trial and be guided by the teacher. The purpose of this RBL is for students to conform the answers according to the theory that has been obtained. The teacher will introduce the materials that have been prepared, and the students will try according to the instructions on the student worksheet. In the implementation of learning, students are very enthusiastic about following the existing process, namely reading practical instructions, assembling tools, taking measurements, taking notes on worksheets, and conducting discussions with friends in groups to conclude the data obtained with guidance from the teacher. The next stage is to present the answers in front of the class according to the results found.

The teacher does this to provide space for students from an early age to be independent, not rigid, and spirited in completing the responsibilities given by the teacher. The purpose of the RBL itself is the University's main mission so that the research culture continues to be developed. Therefore, with RBL, the University hopes that students at lower levels, both elementary and high school levels, continue to do simple research in the classroom or outside the classroom to train students from the start (Schmitt, et al., 2021). Investigative laboratories differ from learning research-based laboratories in that they place more responsibility on students to see the big picture, design 'hypothesis-driven experiments, to increase their intellectual autonomy (Schmitt, et al., 2021).

RBL is a combination of critical thinking and inquiry that encourages students to be active in the learning process in the classroom. In the RBL model, 
students learn new skills and become aspiring scientists to communicate science better to others; students who learn these skills but do not become scientists should be better able to evaluate scientific findings (Warger, 2014). Elementary school students play more than learn. Therefore, teachers have the task of designing innovative learning in improving student academic achievement. RBL is more child-centered and focuses on developing skills, interests, and abilities through engagement and structuring developmentally appropriate academic learning experiences. In addition, it provides autonomous freedom for students to explore, conduct investigations, and try learning experiments from previous mistakes (Taylor \& Boyer, 2020).

The RBL used allows them to practice their metacognitive skills and foster critical attitudes, make predictions, identify causal factors, and reconstruct arguments. It was done and measured through oral presentations in front of the class and each scientific research final report. Currently, CTS must be mastered by students because the rapid development of science and technology will lead to the provision of information, both source, and essence.

RBL procedures enable individuals to equip deductive, inductive, reflective, critical, and creative skills to deal with society's more complex life. RBL allows students to participate in the investigation of problems in discovering and constructing knowledge. The process is active not only mentally but also physically. Constructivist teaching can help the development of thinking skills through the problembased teaching style used by the teacher (Susiani, et al., 2018).

Research with the RBL model with future learning has emerged to answer the needs of Generation $\mathrm{Z}$ and Alpha. There are several strategies to innovate learning practices, such as role-playing, simulation, gamification, social media, educational platforms, and teamwork (Bakhanova, et al., 2020; Brew \& Saunders, 2020). These strategies can also facilitate blended learning, combining face-to-face and virtual, for a dynamic learning process (Gao, et al., 2020). The RBL process implies that students learn in an interactive and applicative way (Rueß, et al., 2016). However, the process can be very tiring for students, depending on the context and their level of involvement (Turner, et al., 2008). However, Lötter \& Jacobs (2020) stated that technology used in education and research could not be underestimated currently. The current generation of students has grown up with information technology, which has impacted learning strategies. They regard technology as a fundamental element for their academic success. Furthermore, students mentioned that smartphones, social media, and educational platforms are socio-pedagogical tools for solving research-based problems (Maumbe, 2014). A new strategy that requires the use of technology is gamification, which is understood as the use of games in an educational-like environment through different digital interfaces that can stimulate student engagement, enjoyment, and participation. However, when the use of new strategies is not directly related to the learning process, they act as a fragmented tool and become an additional burden (Aguiar-Castillo et al., 2020)

\section{Conclusion}

Based on the data analysis and discussion results, it can be concluded that learning using the RBL model affects students' CTS. It can be seen from the difference in the average posttest CTS from the experimental class using the RBL model and the control class using the conventional model, namely $72.70<58.73$. It shows that learning science on light material and its properties with the RBL model is significantly different from learning using the conventional model. It is hoped that the results of this research can be developed in a wider scope in Indonesia in the future with other similar variables or other more creative learning strategies to add insight and improve the quality of learning, especially in science learning. The results of this study include: 1) providing information for teachers as input in the RBL learning model for elementary students in improving CTS, 2) providing alternatives to teachers in making the learning process more efficient and meaningful, 3) providing learning experiences for students with using the RBL learning model, and 4) providing contributions and references for further researchers.

\section{References}

Aarto-Pesonen, L., \& Piirainen, A. (2020). Teacher students' meaningful learning in widening learning worlds. Teaching Education, 31(3), 323342.

https://doi.org/10.1080/10476210.2018.1561662

Aguiar-Castillo, L., Hernández-López, L., De Saá-Pérez, P., \& Pérez-Jiménez, R. (2020). Gamification as a motivation strategy for higher education students in tourism face-to-face learning. Journal of Hospitality, Leisure, Sport and Tourism Education, 27. https://doi.org/10.1016/j.jhlste.2020.100267

Al-Maktoumi, A., Al-Ismaily, S., \& Kacimov, A. (2016). Research-based learning for undergraduate students in soil and water sciences: a case study of hydropedology in an arid-zone environment. Journal of Geography in Higher Education, 40(3), 321339.

https://doi.org/10.1080/03098265.2016.1140130 
Anderson, A. S., \& Good, D. J. (2020). Self-perceptions of critical thinking skills in university students are associated with BMI and exercise. Journal of American College Health, 0(0), 1-7. https://doi.org/10.1080/07448481.2020.1803879

Bağ, H. K., \& Gürsoy, E. (2021). The effect of critical thinking embedded english course design to the improvement of critical thinking skills of secondary school learnersit. Thinking Skills and Creativity, 41. https://doi.org/10.1016/j.tsc.2021.100910

Bakhanova, E., Garcia, J. A., Raffe, W. L., \& Voinov, A. (2020). Targeting social learning and engagement: What serious games and gamification can offer to participatory modeling. Environmental Modelling and Software, 134, 104846. https://doi.org/10.1016/j.envsoft.2020.104846

Bellibaş, M. Ş., \& Gümüş, S. (2021). The effect of learning-centred leadership and teacher trust on teacher professional learning: evidence from a centralised education system. Professional Development in Education, 00(00), 1-13. https://doi.org/10.1080/19415257.2021.1879234

Brew, A., \& Saunders, C. (2020). Making sense of research-based learning in teacher education. Teaching and Teacher Education, 87, 102935. https://doi.org/10.1016/j.tate.2019.102935

Cheong, C. M., \& Cheung, W. S. (2008). Online discussion and critical thinking skills: A case study in a Singapore secondary school. Australasian Journal of Educational Technology, 24(5), 556-573. https://doi.org/10.14742/ajet.1191

Corin, E. N., Jones, M. G., Andre, T., Childers, G. M., \& Stevens, V. (2017). Science hobbyists: active users of the science-learning ecosystem. International Journal of Science Education, Part B: Communication and Public Engagement, 7(2), 161-180. https://doi.org/10.1080/21548455.2015.1118664

Darling-hammond, L., Flook, L., Cook-harvey, C., Barron, B., Flook, L., Cook-harvey, C., Barron, B., Darling-hammond, L., Flook, L., Cook-harvey, C., \& Barron, B. (2019). Implications for educational practice of the science of learning and development. Applied Developmental Science, 0(0), $1-44$.

https://doi.org/10.1080/10888691.2018.1537791

Ennis, R. H. (2015). Critical Thinking: A Streamlined Conception. The Palgrave Handbook of Critical Thinking in Higher Education, 31-47. https://doi.org/10.1057/9781137378057_2

Espinoza-Figueroa, F., Vanneste, D., AlvaradoVanegas, B., Farfán-Pacheco, K., \& RodriguezGiron, S. (2021). Research-based learning (RBL): Added-value in tourism education. Journal of Hospitality, Leisure, Sport and Tourism Education, 28(April). https:// doi.org/10.1016/j.jhlste.2021.100312

Falk, J. H., Pattison, S., Meier, D., Bibas, D., \& Livingston, K. (2018). The contribution of sciencerich resources to public science interest. Journal of Research in Science Teaching, 55(3), 422-445. https://doi.org/10.1002/tea.21425

Facione, P. A. (1990). Executive summary- Critical thinking: A statement of expert consensus for purposes of educational assessment and instruction (The Delphi Report). Retrieved from the Duke Trinity College of Arts \& Sciences. Retrieved from: http://assessment.aas.duke.edu/documents/Del phi_Report.pdf.

Gao, B. W., Jiang, J., \& Tang, Y. (2020). The effect of blended learning platform and engagement on students' satisfaction - - the case from the tourism management teaching. Journal of Hospitality, Leisure, Sport and Tourism Education, 27(September), 100272. https://doi.org/10.1016/j.jhlste.2020.100272

Garrett, T. (2008). Student-centered and teachercentered classroom management: a case study of three elementary teachers. Journal of Classroom Interaction, 43(1), 34-47. Retrieved from: https://eric.ed.gov/?id=EJ829018

Gumus, S. S., Gelen, I., \& Keskin, A. (2013). Value acquisition, critical thinking skills and the performance of 6th grade students. Education 3-13, 41(3), 254-264. https://doi.org/10.1080/03004279.2011.570771

Gustavsson, L., Jonsson, A., Ljung-Djärf, A., \& Thulin, S. (2016). Ways of dealing with science learning: a study based on Swedish early childhood education practice. International Journal of Science Education, 38(11), 1867-1881. https://doi.org/10.1080/09500693.2016.1220650

Kettler, T. (2014). Critical thinking skills among elementary school students: comparing identified gifted and general education student performance. Gifted Child Quarterly, 58(2), 127-136. https://doi.org/10.1177/0016986214522508

Leasa, M., Batlolona, J. R., \& Talakua, M. (2021). Elementary students ' creative thinking skills in science in the Maluku Islands, Indonesia. Creativity Studies, 14(1), 74-89. https://doi.org/10.3846/cs.2021.11244

Leasa, M., Corebima, A. D., \& Batlolona, J. R. (2020). The effect of learning styles on the critical thinking skills in natural science learning of elementary school students. Elementary Education Online, 19(4), 2086-2097. https://doi.org/10.17051/ilkonline.2020.763449

Leasa, M., Sanabuky, Y. L., Batlolona, J. R., \& Enriquez, J. J. (2019). Jigsaw in teaching circulatory system: a learning activity on elementary science classroom. 
Biosfer,

12(2),

122-134.

https://doi.org/10.21009/biosferjpb.v12n2.122-

$\underline{134}$

Leasa, M., Talakua, M., \& Batlolona, J. R. (2016). The development of a thematic module based on Numbered Heads Together (NHT) cooperative learning model for elementary students in Ambon, Moluccas-Indonesia. New Educational Review, 46(4), 174-185. https://doi.org/10.15804/tner.2016.46.4.15

Leasa, M., \& Corebima, A. D. (2017). The effect of numbered heads together (NHT) cooperative learning model on the cognitive achievement of students with different academic ability. Journal of Physics: Conference Series, 795. Https://Doi.Org/10.1088/1742$6596 / 755 / 1 / 011001$

Lötter, M. J., \& Jacobs, L. (2020). Using smartphones as a social constructivist pedagogical tool for inquiry-supported problem-solving: an exploratory study. Journal of Teaching in Travel and Tourism, 20(4), 347-363. https://doi.org/10.1080/15313220.2020.1715323

Maumbe, K. (2014). Teaching and learning in recreation and tourism: a comparison of three instructional methods. Journal of Teaching in Travel and Tourism, 14(4), 365-385. https://doi.org/10.1080/15313220.2014.955305

National Research Council. (2014). STEM learning is everywhere: Summary of a convocation on building learning systems. Washington, DC: The National Academies Press.

Polat, Ö., \& Aydın, E. (2020). The effect of mind mapping on young children's critical thinking skills. Thinking Skills and Creativity, 38. https://doi.org/10.1016/j.tsc.2020.100743

Rueß, J., Gess, C., \& Deicke, W. (2016). Forschendes Lernen und forschungsbezogene Lehre empirisch gestützte Systematisierung des Forschungsbezugs hochschulischer Lehre. Zeitschrift Für Hochschulentwicklung, 11(2). https://doi.org/10.3217/zfhe-11-02/02

Samaras, S. A., Adkins, C. L., \& White, C. D. (2021). Developing critical thinking skills: Simulations vs. cases. Journal of Education for Business, 0(0), 1-7. https://doi.org/10.1080/08832323.2021.1932703

Susiani, S. T., Salimi, M., \& Hidayah, R. (2018). Research based learning (RBL): How to improve critical thinking skills? SHS Web of Conferences, 42, 00042.

https://doi.org/10.1051/shsconf/20184200042

Schmitt, F. J., Frielingsdorf, S., Friedrich, T., \& Budisa, N. (2021). Courses based on iGEM/BIOMOD competitions are the ideal format for researchbased learning of xenobiology. ChemBioChem, 22(5),

818-825. https://doi.org/10.1002/cbic.202000614

Smith, P., \& Rust, C. (2011). The potential of researchbased learning for the creation of truly inclusive academic communities of practice. Innovations in Education and Teaching International, 48(2), 115-125. https://doi.org/10.1080/14703297.2011.564005

Solihati, N., \& Hikmat, A. (2018). Critical thinking tasks manifested in indonesian language textbooks for senior secondary students. SAGE Open, 8(3). https://doi.org/10.1177/2158244018802164

Taylor, M. E., \& Boyer, W. (2020). Play-based learning: evidence-based research to improve children's learning experiences in the kindergarten classroom. Early Childhood Education Journal, 48(2), 127-133. https://doi.org/10.1007/s10643-01900989-7

Tee, K. N., Leong, K. E., \& Abdul Rahim, S. S. (2018). The mediating effects of critical thinking skills on motivation factors for mathematical reasoning ability. Asia-Pacific Education Researcher, 27(5), 373382. https:// doi.org/10.1007/s40299-018-0396-z

Tuaputty, H., Leasa, M., Corebima, A. D., \& Batlolona, J. R. (2021). The Correlation between Critical Thinking Skills and Cognitive Learning Outcomes. Elementary Education Online, 20(1), 302317.

https://doi.org/10.17051/ilkonline.2021.01.029

Turner, N., Wuetherick, B., \& Healey, M. (2008). International perspectives on student awareness, experiences and perceptions of research: implications for academic developers in implementing research-based teaching and learning. International Journal for Academic Development, 13(3), 199-211. https://doi.org/10.1080/13601440802242333

van der Zanden, P. J. A. C., Denessen, E., Cillessen, A. H. N., \& Meijer, P. C. (2020). Fostering critical thinking skills in secondary education to prepare students for university: teacher perceptions and practices. Research in Post-Compulsory Education, 25(4), 394-419. https://doi.org/10.1080/13596748.2020.1846313

van Peppen, L. M., Verkoeijen, P. P. J. L., Heijltjes, A. E. G., Janssen, E. M., Koopmans, D., \& van Gog, T. (2018). Effects of self-explaining on learning and transfer of critical thinking skills. Frontiers in Education, 3(November), 1-11. https://doi.org/10.3389/feduc.2018.00100

Vidergor, H. E. (2018). Effectiveness of the multidimensional curriculum model in developing higher-order thinking skills in elementary and secondary students. Curriculum Journal, 29(1), 95-115. https://doi.org/10.1080/09585176.2017.1318771

Volet, S., Seghezzi, C., \& Ritchie, S. (2019). Positive emotions in student-led collaborative science 
activities: relating types and sources of emotions to engagement in learning. Studies in Higher Education, 44(10), 1734-1746. https://doi.org/10.1080/03075079.2019.1665314

Wang, H. H., Chen, H. T., Lin, H. S., Huang, Y. N., \& Hong, Z. R. (2017). Longitudinal study of a cooperation-driven, socio-scientific issue intervention on promoting students' critical thinking and self-regulation in learning science. International Journal of Science Education, 39(15), 2002-2026.

https://doi.org/10.1080/09500693.2017.1357087

Wartono, W., Hudha, M. N., \& Batlolona, J. R. (2018). How are the physics critical thinking skills of the students taught by using inquiry-discovery through empirical and theorethical overview? Eurasia Journal of Mathematics, Science and Technology Education, 14(2), 691-697. https://doi.org/10.12973/ejmste/80632

Wagner, G. E. (2014). Research-Based Learning. Innovative Strategies for Teaching in the Plant Sciences, 6182. https://doi.org/10.1007/978-1-4939-0422-8_5

Wessels, I., Rue $\beta$, J., Gess, C., Deicke, W., \& Ziegler, M. (2020). Is research-based learning effective? Evidence from a pre-post analysis in the social sciences. Studies in Higher Education, 0(0), 1-15. https://doi.org/10.1080/03075079.2020.1739014

Yeoman, K. H., \& Zamorski, B. (2008). Investigating the impact on skill development of an undergraduate scientific research skills course. Bioscience Education, 11(1), 1-14. https://doi.org/10.3108/beej.11.5 